\title{
Land use drives change in amazonian tree species
}

\author{
IMA CÉLIA G. VIEIRA \\ Museu Paraense Emilio Goeldi, Av. Magalhães Barata, 376, 66040-170 Belém, PA, Brazil \\ Manuscript received on February 15, 2019; accepted for publication on June 17, 2019
}

How to cite: VIEIRA ICG. 2019. Land use drives change in amazonian tree species. An Acad Bras Cienc 91: e20190186. DOI 10.1590/0001-3765201920190186.

\begin{abstract}
The Amazonian rainforest has been subjected to exceptionally high rates of land use change (LUC), primarily for pasture. We present here an analysis of the impact of LUC on trees from studies made in Pará state. LUC results in drastic declines in native species richness, changes species composition and impacts community resilience and ecosystem services provided by the Amazonian rainforest. Given that secondary forests are expanding in Amazonia we argue that this regrowth forest should be taken into account when planning conservation in this region.
\end{abstract}

Key words: Amazon region, biodiversity, deforestation, land use.

\section{INTRODUCTION}

The Brazilian Amazon region (Amazonia) is under increasing anthropogenic pressure and climate change. This region is among the most heavily altered Brazilian regions reaching $22 \%$ of deforestation in 2017 (INPE 2017). Major drivers of forest loss include land use change (LUC), overexploitation, mining and hydroelectric dams (Fearnside 2005, Vieira et al. 2008).

Pastures remain as the dominant land use in Amazonia, occupying $65 \%$ of deforested land (Almeida et al. 2016) and with the regional herd reaching 85 million heads (IBGE 2016). There has been a prominent decline in Amazonian deforestation over the last decade, from the record of $27,772 \mathrm{~km}^{2}$ in 2004 to $6,947 \mathrm{~km}^{2}$ in 2017 (INPE 2017) which might be a result of law enforcement to curb illegal deforestation (Assunção et al. 2012).

E-mail: ima@museu-goeldi.br

ORCid: https://orcid.org/0000-0003-1233-318X
Large-scale deforestation reduces precipitation in Amazonia, and increases the duration of dry season. This drives changes in fire frequency (Alencar et al. 2006) and biogeochemical feedbacks, which could lead to savannization with changes in vegetation composition and structure, affect the water resources, carbon emissions, and eventually lead to a new climate-biosphere vegetation dynamic equilibrium (Oyama and Nobre 2003). The emerging evidences of an Amazonia in transition (Davidson et al. 2012) highlights the need for understanding the impacts on biodiversity associated to land use changes.

\section{IMPACTS OF LAND USE CHANGE ON TREE DIVERSITY}

Land use change accounts for most of the biodiversity loss in Amazonia due to the cooccurring mechanisms of habitat loss and fragmentation. The expansion of cattle pastures across much of this region has resulted in 
fragmentation with increased edge effects, and the isolation of remaining forest patches (Laurance et al. 2011). For example, $6.4 \%$ of remaining forest habitats were found within a radius of $100 \mathrm{~m}$ of a forest edge in a study that evaluated an area of 1.12 million $\mathrm{km}^{2}$ ( $>80 \%$ of Amazonia affected by deforestation and selective logging) (Broadbent et al. 2008). The process of fragmentation includes tree dieback (Laurance 2000), changes in mutualistic and trophic interactions between species (Peres et al. 2010) and synergistic actions with other factors, such as susceptibility to fire (Alencar et al. 2006) that lead to local species extinctions.

LUC also results in drastic declines in tree native species richness and wholesale changes in species composition (Figure 1). In comparison with primary forests, pasture lands are characterized by a small number of generalist and edge-tolerant, or gap-specialist forest species. Possibly the most negative indirect impact of pastures (i.e. other than the actual clearance itself) on biodiversity is through fires that are used for forest clearing or pasture maintenance and then escape into surrounding areas of forest (Barlow et al. 2003).

Recent study of Amazon Tree Diversity Network-ATDN (ter Steege et al. 2015) suggested that historical and ongoing forest loss may cause population declines of $>30 \%$ in one-quarter to one-half of all Amazonian tree species by 2050 . The synergistic and feedback effects of LUC coupled with anthropogenic climate change have an enormous potential to drive further significant biodiversity losses during the $21^{\text {st }}$ century (Peres et al. 2010). Specifically, increased mortality of canopy trees due to dryer conditions may both open up the canopy and create large stocks of woody debris resulting in elevated forest flammability (Alencar et al. 2006). In this context of impeding major climate change impacts, loss of biodiversity could impact community resilience and amplify erosion of vital ecosystem services provided by Amazonia (Brando et al. 2014).

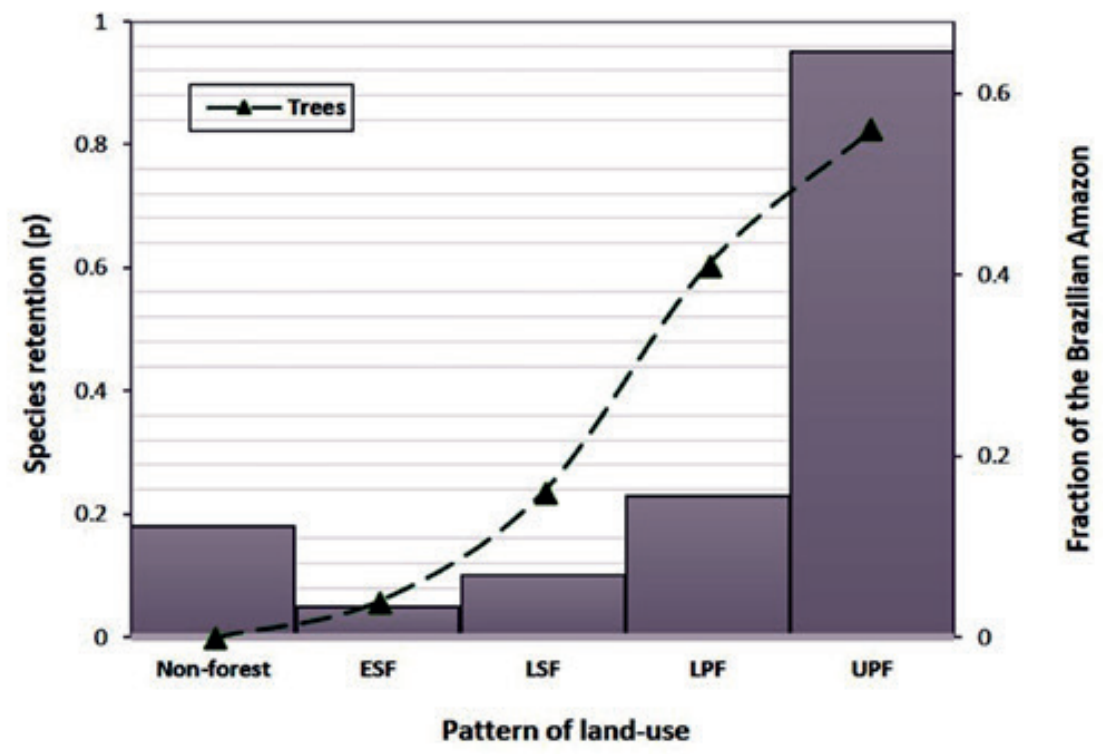

Figure 1 - Patterns of forest tree species retention (p) across a gradient of land-use and land cover in the Brazilian Amazonia, including cattle pastures, early secondgrowth (ESF), late secondary forest (LSF), selectively-logged primary forest (LPF) and undisturbed primary forest (UPF). Retention is defined as the proportion of species occurring throughout the entire forest matrix that occupies any given land-use. Gray shading indicates the overall proportional areas currently represented by these land-uses. Data from: Vieira, ICG, unpublished data. 


\section{SECONDARY FORESTS AND THE FUTURE OF THE AMAZONIAN RAINFOREST}

Human alteration of Amazonian ecosystems has resulted in the expansion of secondary forest ("capoeiras") at the expense of primary forest. The extent of secondary forest in Amazonia in 2014 was about $165,000 \mathrm{~km}^{2} ; 63,606 \mathrm{~km}^{2}$ in the State of Pará. If land use trends continue, secondary forest could become the predominant forest type in the future Amazonian landscape. About 25\% of the areas felled is abandoned after initial use and regenerates as secondary forest (Almeida et al. 2016). These forests are important landscape elements for the conservation of biodiversity and the maintenance of ecosystem services (Vieira and Gardner 2012, Chazdon 2014).

Reforestation can occur through active processes (tree planting) or through spontaneous natural regeneration following abandonment of agricultural clearings. What does and does not constitute a "forest" is a topic of considerable debate (Chazdon et al. 2016). Clearly, different regeneration trajectories lead to a wide range of ecological outcomes (Figure 2).

Secondary forest supplies various ecosystem services and contributes to wildlife conservation and should be considered as recovering forests, as they re-establish the organic functions of the soil, and constitute a reserve of regional native seeds and fruits that allows for the maintenance of the floristic diversity. Studies from the $2 \mathrm{ndFOR}$ International Research Network (Poorter et al. 2016, Rozendaal et al. 2019) have shown that a region where oldgrowth forest has been cleared, secondary forests can take 30 years to recompose the original biomass and 300 years to match the diversity of tree species that existed at the time of destruction. The carbon and biodiversity of secondary forests recovered to more than $80 \%$ of the levels found in undisturbed primary forests (Lennox et al. 2018). This result is important for climate change mitigation and biodiversity conservation, however, despite the potential ecological and socioeconomic significance of secondary forests, they
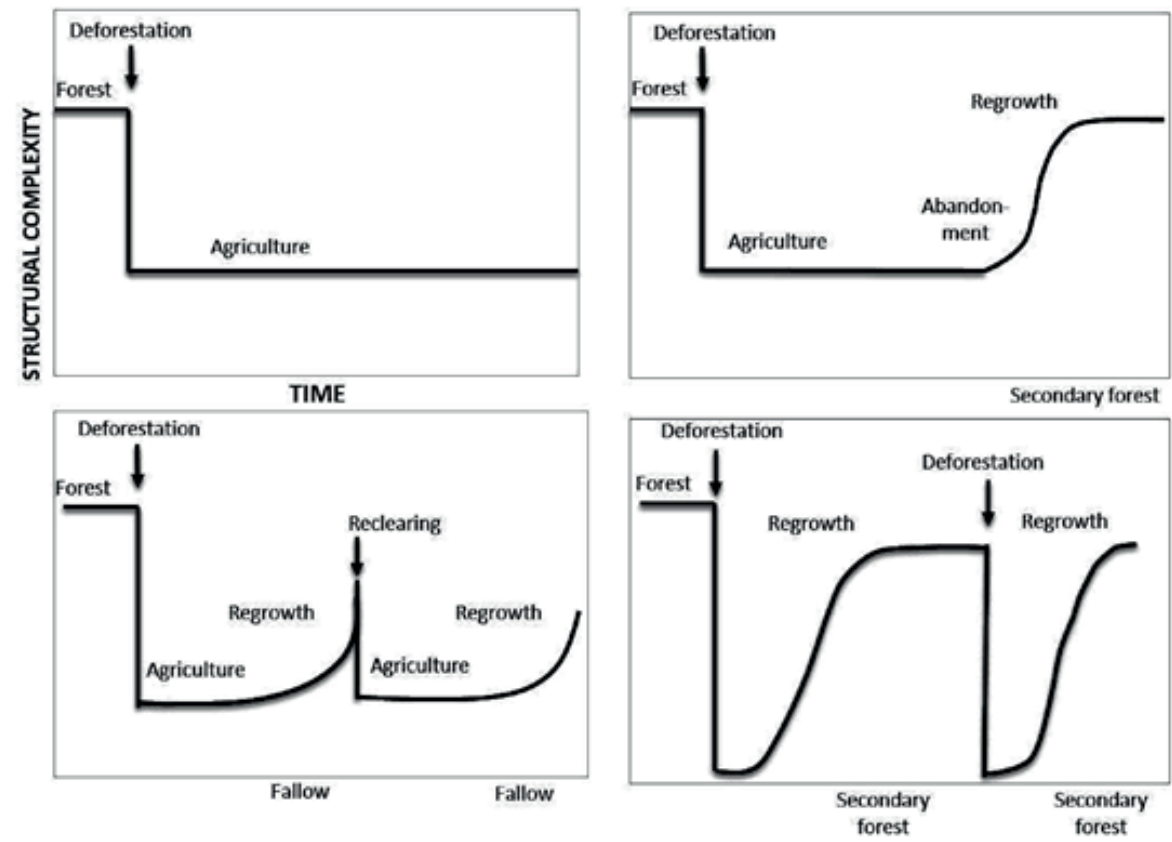

Figure 2 - Different trajectories of natural regeneration following land use practices. Vegetation structure can either remain at lower level or develop if the land is allowed to regrow back into a forest. Adapted from Ramankutty et al. (2007). 
are frequently recleared and so do not provide any conservation gains (Vieira et al. 2014).

The growing consensus is that the conservation of tropical biodiversity cannot be centered solely on protected areas, and instead it will require action in all land use types across landscapes and regions (Aide 2000). Secondary forests, from an environmental point of view, contribute to the removal of carbon from the atmosphere, the re-establishment of hydrological functions, the recovery of biodiversity, the reduction of potential nutrient losses by erosion and lixiviation, and the decrease in fire sensitivity of the landscape (Almeida et al. 2010; Vieira and Gardner 2012). Beyond the overriding importance of secondary forests, it is important to note that they also play a significant and often overlooked role in conservation in the fragmented landscape of eastern Amazonia and for secondary forests to achieve the socio-ecological potential they must be incorporated as key elements of landscape management and conservation planning.

\section{CONCLUSIONS}

Amazonia is highly resilient to land use change. However, the size and intensity of transformations of the Amazonian rainforest have changed substantially since 1990. Pasture, soybean and oil palm plantations now occupy much larger areas than shifting agriculture in eastern Amazonia. These areas have been subject to intensive land use and accidental fire dominates the humanmodified landscape in this region. The vigorous regeneration of forest may be declining. Primary and secondary forest fragments are being burned and the degradation of the landscape is notorious. Continuous deforestation, fragmentation, fire and climate change will certainly affect secondary regrowth and will create more simplified ecosystems, with a predominance of increasingly fire-resistant tree species. The only way to contain the accelerated process of biotic depletion in eastern Amazonia is to promote sustainable territories, based on economic-ecological zoning and land use regulations that allow the biotic components of the Amazonian ecosystems to persist in the landscape.

\section{ACKNOWLEDGMENTS}

The author is supported by Conselho Nacional de Desenvolvimento Científico e Tecnológico (CNPq) Research Productivity Scholarship (Proc.3087782017-0). I am grateful to Msc Fabiana Pereira for helping with the figures.

\section{REFERENCES}

AIDE TM, ZIMMERMMAN JK, PASCARELLA JB, RIVERA L AND MARCANO-VEGA H. 2000. Forest regeneration in a chronosequence of tropical abandoned pastures: implications for restoration ecology. Restor Ecol 8: 328-338.

ALENCAR A, NEPSTAD D AND DIAZ MCV. 2006. Forest understory fire in the Brazilian Amazon in ENSO and Non-ENSO years: area burned and committed carbon emissions. Earth Interact 10: 101-117.

ALMEIDA AS, STONE TA, VIEIRA ICG AND DAVIDSON E. 2010. Nonfrontier Deforestation in the Eastern Amazon. Earth Interact 14: 1-15.

ALMEIDA CA, COUTINHO AC, ESQUERDO JCDM, ADAMI M, VENTURIERI A, DINIZ CG, DESSAY N, DURIEUX L AND GOMES AR. 2016. High spatial resolution land use and land cover mapping of the Brazilian Legal Amazon in 2008 using Landsat-5/TM and MODIS data. Acta Amazonica 46: 291-302.

ASSUNÇÃO J, GANDOUR CC AND ROCHA R. 2012. Deforestation slowdown in the Legal Amazon: prices or policies Climate Policy Initiative (CPI) Working Paper. Rio de Janeiro: Pontífica Universidade Católica, 37 p.

BARLOW J, LAGAN BO AND PERES CA. 2003. Morphological correlates of fire-induced tree mortality in a central Amazonian forest. J Trop Ecol 19: 291-299.

BRANDO PM, BALCH JK, NEPSTAD D, MORTON D, PUTZ FE, COE MT, SILVÉRIO D AND MACEDO M. 2014. Abrupt increases in Amazonian tree mortality due to drought-fire interactions. Proc Natl Acad Sci111: $6347-$ 6352.

BROADBENT EN, ASNER GP, KELLER M, KNAPP DE, OLIVEIRA PJC AND SILVA JN. 2008. Forest fragmentation and edge effects from deforestation and 
selective logging in the Brazilian Amazon. Biol Conserv 14: $1745-1757$.

CHAZDON RL. 2014. Second Growth: The Promise of Tropical Forest Regeneration in an Age of Deforestation, $1^{\text {st }}$ ed., Chicago (Illinois): University of Chicago Press, $449 \mathrm{p}$.

CHAZDON, RL, BRANCALION, PHS, LAESTADIUS L, BENNETT-CURRY A, BUCKINGHAM K, KUMAR C, MOLL-ROCEK J, VIEIRA ICG AND WILSON SJ. 2016. When is a forest a forest? Forest concepts and definitions in the era of forest and landscape restoration. Ambio 45: 538-550.

DAVIDSON EA ET AL. 2012. The Amazon basin in transition. Nature 481: 321-328.

FEARNSIDE PM. 2005. Deforestation in Brazilian Amazonia: history, rates, and consequences. Conserv Biol 19: 680688.

IBGE. 2016. Pesquisa Pecuária Municipal-2016. Disponível em https://sidra.ibge.gov.br/pesquisa/ppm/quadros/ brasil/2016. Acesso em 2 de julho de 2018.

INPE. 2017. Projeto Prodes: Monitoramento de Floresta Amazônica Brasileira por satélite. http://www.obt.inpe.br/ prodes/index.php.

LAURANCE WF. 2000. Do edge effects occur over large spatial scales? Trends Ecol Evol 15: 134-135.

LAURANCE WF ET AL. 2011. The fate of Amazonian forest fragments: a 32-year inverstigation. Biol Conserv 144: 5667.

LENNOX GD ET AL. 2018. Second rate or a second chance? Assessing biomass and biodiversity recovery in regenerating Amazonian forests. Global Change Biol 24: 5680-5694.

OYAMA MD AND NOBRE CA. 2003. A new climatevegetation equilibrium state for Tropical South America. Geophys Res Lett 30: 2199-2203.

PERES CA, GARDNER TA, BARLOW J, ZUANON J, MICHALSKI F, LEES AC, VIEIRA ICG, MOREIRA FMS AND FEELEY KJ. 2010. Biodiversity conservation in human-modified Amazonian forest landscapes. Biological Conservation 143: 2314-2327.

POORTER L ET AL. 2016. Biomass resilience of Neotropical secondary forests. Nature 530: 211-214.

RAMANKUTTY N, GIBBS HB, ACHARD F, DEFRIES R, FOLEY JA AND HOUGHTON RA. 2007. Challenges to estimating carbon emissions from tropical deforestation. Glob Change Biol 13: 51-66.

ROZENDAAL DMA ET AL. 2019. Biodiversity recovery of neotropical secondary forests. Sci Adv 5(3): eaau3114.

TER STEEGE H ET AL. 2015. Estimating the global conservation status of more than 15,000 Amazonian tree species. Sci Adv 1(10): e1500936.

VIEIRA, ICG AND GARDNER T. 2012. Florestas secundárias tropicais: ecologia e importância em paisagens antrópicas. Bol Mus Para Emílio Goeldi 7: 191-194.

VIEIRA ICG, GARDNER T, FERREIRA J, LEES A AND BARLOW J. 2014. Challenges of governing second-growth forests: A Case Study from the Brazilian Amazonian State of Para. Forests 5: 1737-1752.

VIEIRA ICG, TOLEDO PM, SILVA JMC AND HIGUCHI H. 2008. Deforestation and threats to the biodiversity of Amazonia. Braz J Biol 68: 949956. 